\title{
Möllermodellen
}

\section{Svensk socialförsäkring 1944-51}

\section{PER GUNNAR EDEBALK}

Gustav Möller var tongivande svensk socialpolitiker åren efter krigsslutet. Den modell för socialförsäkring som han sökte genomdriva baserades på den så kallade minimistandardprincipen och skulle ge grundtrygghet. Modellen blev emellertid inte offentligt formulerad i sin helhet. I artikeln görs ett försök att rekonstruera modellen och den relateras till den allmänna socialförsäkringsutvecklingen i Sverige. Härigenom kan Möllers självständighet som socialförsäkringsideolog belysas.

Gustav Möller föddes 1884. Han kom tidigt att bli en tongivande person inom det socialdemokratiska partiet. Mellan åren 1913 och 1924 var han medredaktör i tidskriften Tiden och 1921-24 chefredaktör för tidningen Social-Demokraten. Han innehade posten som partisekreterare 1916-40 och var riksdagsman från och med 1918. Som socialminister debuterade han 1924-26 och sedan 1932 var han, med ett par korta undantag, den ledande socialpolitiske företrädaren i regeringen fram till hösten 1951. Han dog 1970.

Per Gunnar Edebalk är docent i socialt arbete vid Socialhögskolan, Lunds universitet. Han har forskat om socialförsäkringar och äldreomsorg.
Under 1980-talet kom Gustav Möller på nytt i blickpunkten. Hans unika ställning i socialpolitikens historia, hans starka personlighet och hans liv som privatperson har uppmärksammats (Lindblom-Jönsson 1986). Ett särskilt intresse har knutits till hans syn på välfärdsstatens förvaltning och på tjänstemannarekryteringen (Hermansson-Svensson 1989, Nyström 1983, Rothstein 1984 och 1987). Omkring år 1990 kom en av Möllers huvudidéer, grundtryggheten, att föras fram på nytt som en sätt att förnya det svenska socialförsäkringssystemet (Ds 1993:51).

I denna artikel fokuseras intresset på Möllers modell för grundtrygghet. Det var speciellt under perioden 1944-51, den 
s.k. skördetiden, som modellen skulle materialiseras. Ekonomiska och politiska förutsättningar syntes då föreligga för införandet av modellen. Så hade fallet inte varit under mellankrigstiden.

Med Möllers modell för grundtrygghet menar vi helt enkelt hans syn på socialförsäkringssystemet vars huvuddelar är pensioner, sjukförsäkring, yrkesskadeförsäkring (numera arbetsskadeförsäkring och tidigare olycksfallsförsäkring) och arbetslöshetsförsäkring. Vi koncentrerar oss på dessa huvuddelar och skall främst se dem utifrån fem aspekter.

1) Vilken anslutningsprincip har valts och vem omfattas?

2) Vilka förmåner utgår?

3) Vilken ersättningsprincip väljs? Här finns inom socialförsäkringen fyra principer: enligt inkomstprövning (ju högre samtida inkomst desto lägre ersättning), enligt minimistandardprincip (enhetsersättning lika för alla), enligt inkomstbortfallsprincipen (ju större inkomstförlust desto större ersättning) samt enligt avgiftsinbetalningar (ju mer som betalas desto större ersättning).

4) Hur finansieras systemet (skatter, egenavgifter eller arbetsgivaravgifter)?

5) Hur sker samordningen av systemet och hur ser den administrativa apparaten ut?

Möllers modell blev inte färdigbyggd. Vi skall söka rekonstruera hela modellen och ställa den i relation till den svenska socialförsäkringsutvecklingen före och efter perioden 1944-51. Härigenom kan vi tydligt se dess unika drag och hur självständig Möller var som socialförsäkringsideolog.

\section{Den svenska bakgrunden}

Den svenska socialförsäkringens historia brukar anses inledd i och med S. A. Hedins riksdagsmotion 1884 (Elmér 1960, Olsson 1990). Impulsen kom från reformerna i det kejserliga Tyskland i början av 1880-talet. Utredandet kom tidigt i gång efter Hedins motion men resultaten blev magra. Så sent som 1910 fanns endast 1901 års lag om ersättningsplikt vid olycksfall (som hade en begränsad räckvidd) och en svagt utvecklad, frivillig sjukkasserörelse som efter riksdagsbeslut 1891 och 1910 arbetade med statliga subventioner.

Starten var alltså långsam men några år efter sekelskiftet skedde en socialpolitisk islossning och under åren 1907-1910 framträder samtliga partigrupperingar som mer eller mindre utpräglade reformivrare (Edebalk 1993). Man kan uttrycka det så att en ny syn på staten och dess möjligheter att lösa de sociala frågorna hade blivit allmänt etablerad. En mycket stor riksdagsmajoritet fattade år 1913 beslut om en allmän pensionsförsäkring (Elmér 1960). Denna skulle omfatta hela folket. Konstruktionsmässigt bestod pensionsförsäkringen av två delar. Den första var en avgiftspension, med idérötter i den tyska tvångsförsäkringen och byggd på försäkringsmässiga grunder. Den andra delen var en skattefinansierad inkomstprövad tilläggspension. Denna del infördes för att försäkringen skulle få en omedelbar effekt och den hade sin udd riktad mot en stigmatiserande fattigvård.

År 1916 fattades beslut om olycksfallsförsäkring som byggde på försäkringstvång. Motivet för detta var bland annat 
att den nya lagen skulle få en större omfattning än den gamla. Även mindre företag skulle inkluderas. Med ersättningsplikt i sådana fall skulle en olycksfallsersättning kunna bli ruinerande för arbetsgivaren och den enskilde arbetarens trygghet skulle bli mer eller mindre illusorisk. Till detta motiv hör att det framlagda förslaget innehöll väsentligt ökade ersättningsbelopp. Försäkringen skulle i princip täcka hela arbetsmarknaden och ersättning skulle utgå enligt inkomstbortfallsprincipen.

Innan en regeringsproposition framlagts, detta skedde i april 1916, tillsattes den s.k. socialförsäkringskommittén (Edebalk 1993). Denna skulle bland annat utreda frågan om obligatorisk sjukförsäkring och i direktiven hänvisas direkt till den kommande olycksfallsförsäkringen.

Socialförsäkringskommittén avlämnade sitt betänkande 1919. Eftersom den frivilliga sjukförsäkringen inte nådde de mest behövande föreslogs en obligatorisk sjukförsäkring. Den allmänna sjukförsäkringen tänktes omfatta $\mathrm{i}$ stort sett hela den arbetsföra befolkningen över 16 år. Sjukpenningen skulle utgå enligt inkomstbortfallsprincipen och beloppet hade anpassats till olycksfallsförsäkringen. En samordning skulle alltså ske.

Idén om en allmän obligatorisk sjukförsäkring var starkt politiskt förankrad under senare delen av 1910-talet (Edebalk 1993). Det framgår bland annat av ett riksdagsutlătande 1920 där det hette vatt sjukförsäkringsfrågan, med hänsyn till dess stora betydelse för hela vårt lands befolkning bör med det snaraste bringas till sin lösningu (Fk 2 Tillf. utskott 1920:29, s. 6). 1910-talet markerade socialförsäkringstankens definitiva genombrott i Sverige. Socialförsäkringen skulle vara generell och omfatta i princip hela befolkningen. För ersättningarna gällde att inkomstbortfallsprincipen var accepterad. För arbetslöshetsförsäkringen var det s.k. Gentsystemet aktuellt men ett förslag från socialförsäkringskommittén kom först 1922 (SOU 1922:59).

1920-talet inleddes med en svår deflationskris och även sedan denna övervunnits kvarstod en hög arbetslöshet. Under 1920-talet skedde en påtaglig polarisering mellan borgerliga och socialistiska partier, där de förra innehade riksdagsmajoriteten. Enligt förhärskande ekonomiska idéer skulle statsbudgeten vara balanserad (vilket innebar strama utgiftsprövningar). Den så kallade besparingskommittén slog i sitt betänkande (SOU 1925:8) fast att man av ekonomiska skäl måste avvisa tanken på en allmän sjukförsäkring. Kommittén menade också att den frivilliga sjukförsäkringen måste effektiviseras: statsbidragen borde höjas och prestationerna förbättras men framför allt borde statsbidraget begränsas till en enda sjukkassa inom ett visst område.

Perioden 1926-30 avlämnade regeringar av olika partifärg propositioner rörande reformering av den statsunderstödda sjukkasserörelsen. Det hette också att detta skulle skapa administrativa förutsättningar för ett framtida obligatorium. Först 1932, efter en proposition från den Ekmanska regeringen 1931 (Proposition 1931:75), trädde reformen i kraft. Lösningen innebar att det tillskapades lokalsjukkassor, som fick monopol 
inom ett visst geografiskt område och skulle handha kortare sjukdomsfall, och centralsjukkassor som svarade för längre sjukdomstider.

Frågan om offentlig arbetslöshetsförsäkring hade diskuterats sedan före första världskriget. Speciellt efter 1920 var fackföreningsrörelsen en kraftig påtryckningsgrupp (Edebalk 1975). Primärt önskade fackföreningsrörelsen ett Gentsystem. Den icke-socialistiska majoriteten i riksdagen accepterade emellertid inte Gentsystemet under 1920-talet dels eftersom man inte önskade stärka fackföreningsrörelsen (1920-talets arbetslöshet ansågs förorsakad av en alltför aggressiv lönepolitik) dels eftersom omfattningen skulle bli otillfredsställande (den stora lantarbetargruppen till exempel var svagt organiserad). Socialdemokraterna, som i riksdagen försökt driva igenom ett positivt beslut om arbetslöshetsförsäkring, lyckades först 1934 få med delar av borgerligheten på en kompromisslösning. Denna innebar främst en statsbidragskonstruktion som utgick från en behovsprincip samt stränga försäkringsregler i övrigt. De arbetslöshetskassor som bildades på basis av den nya förordningen var "erkända». Bildandet gick dock trögt. Till och med 1940 hade endast 14 erkända arbetslöshetskassor upprättats (Edebalk 1975). År 1941 genomfördes emellertid en rejäl förbättring av statsbidragen och försäkringsvillkoren något som gav starka incitament för fackförbunden att inrätta erkända arbetslöshetskassor.

Den allmänna pensionsförsäkring som riksdagen beslutat 1913 kom i allt väsentligt att bestå till och med 1936. I den sam- hällsekonomiska situation som rådde i början av 1920-talet utsattes den för attacker och statens besparingskommitté föreslog att avgiftsdelen skulle öka på bekostnad av understödsdelen. Utifrån en annan utgångspunkt, nämligen att många gamla tvangs anlita fattigvården trots pensionen, utarbetade Gustav Möller en motion, vilken lades fram som en socialdemokratisk gruppmotion till 1928 års riksdag (motion Fk 1928:169). En genomgripande revision efterlystes och en utredning föreslogs. Den mest rationella lösningen, enligt motionen, var att det allmänna helt tog över finansieringen av folkpensionen och att pensionerna dyrortsrelaterades. Den begärda utredningen tillsattes 1928 och avlämnade sitt slutbetänkande 1934 (SOU 1934:18). Detta bildade underlag för 1935 års pensionsreform (i kraft 1937). De viktigaste inslagen var en förstärkning av pensionsbeloppen och en reduktion av avgiftsdelen: begreppet folkpension efterträdde begreppet pensionsförsäkring.

År 1937 begärde riksdagen en översyn rörande den sociala hjälpverksamheten varvid särskilt frågan om en rationell organisation borde beaktas (Andra LU 1937:50). I början av år 1938 tillsattes en kommitté som antog namnet socialvårdskommittén. Socialministern, Gustav Möller, framhöll i direktiven att översynen inte kunde begränsas till att avse endast åtgärder för att skapa enhetlighet. Också socialvårdens materiella innehåll borde granskas. 


\section{Förslag och reformer 1944-48}

Under världskrigets sista år, då planerna för efterkrigstidens samhälle drogs upp, fanns ett påtagligt reformintresse hos samtliga politiska partier (Baldwin 1990, Lewin 1967, Olsson 1990). I en artikel år 1944 uttryckte socialvårdskommitténs orförande, Bernhard Eriksson, något som sannolikt de flesta ledande politiker kunde ställa sig bakom: „Om vårt folk under krigsåren förmått bära de för krigsberedskapen nödvändiga personliga och ekonomiska bördorna, bör vi även förmå bära kostnaderna för en mera omfattande hjälp till sjuka, åldringar och arbetslösau (Eriksson 1944, sid 155). Alldeles särskilt, menade Eriksson, borde man sörja för att de gamla fick en tryggare och ljusare ålderdom. Den första stora socialförsäkringsreformen efter kriget kom följdriktigt att gälla folkpensionen.

\section{Folkpensionen}

År 1946 antog en i princip enhällig riksdag en ny lag om folkpensionering. Proposition härom hade lämnats av Gustav Möller i april månad (Proposition 1946:220). Den nya folkpensioneringen hade byggts upp med målsättningen att pensionärerna skulle slippa gå till fattigvården.

Den allmänna ålderspensionen skulle utgå till alla som fyllt 67 år. Beloppet var ett enhetsunderstöd, 1000 kronor om året för en ensamstående och 1600 kronor till äkta makar. Till pensionen kom olika tilllägg, bland annat ett inkomstprövat och dyrortsgrupperat bostadstillägg. Pensio- nerna skulle i allt väsentligt finansieras via statsbudgeten.

Socialvårdskommittén hade gjort förarbetet till pensionsreformen. I det betänkande som publicerades 1945 (SOU 1945: 46) presenterades tre alternativ. De två första byggde på inkomstprövade pensioner, det tredje på minimistandardprincipen. I samtliga alternativ hade avgiftspensionen eliminerats och beloppen anpassats så att fattigvård skulle onödiggöras. Högern och bondeförbundet tog tidigt ställning för enhetspensionen medan socialdemokraterna och folkpartiet var splittrade (Elmér 1960, Kangas-Palme 1989, Olsson 1990).

Regeringen, som sedan sommaren 1945 var rent socialdemokratisk, tvekade länge. Gustav Möller var en stark företrädare för enhetspensionen medan majoriteten med finansminister Wigforss i spetsen förordade inkomstprövade pensioner. Framför allt statsfinansiella skäl motiverade sådana. Efter diverse turer, där slutligen den socialdemokratiska riksdagsgruppen med stor majoritet gav sitt stöd för enhetspensionen, avlämnade Möller sin proposition till riksdagen. I allt väsentligt överensstämde denna med socialvårdskommitténs tredje alternativ.

En enhetspension enligt minimistandardprincipen aktualiserar frågan om indexreglering. Särskilt folkpartiet förordade vid 1946 års riksdag en indexreglering av pensionerna (Elmér 1960, Ohlin 1975, Möller 1971). Möller själv motsatte sig en indexreglering bland annat eftersom han räknade med fallande priser då världshandeln kom i gång på allvar efter kriget. Om, emellertid, en prishöjning 
skulle ske lovade Möller under riksdagsdebatten att pensionärerna skulle få kompensation. Vid prishöjningar skulle följaktligen särskilda beslut fattas om dyrtidstilllägg.

\section{Allmän sjukförsäkring}

Socialvårdskommittén avlämnade sitt betänkande angående sjukförsäkring 1944 (SOU 1944:15), alltså året före pensionsbetänkandet. Sjukförsäkringen föreslogs bli allmän och obligatorisk och den skulle omfatta både sjukpenning och sjukvård. Sjukvårdsförsäkringen omfattade ersättning för läkarvårdsutgifter, läkemedel och sjukhusvård.

Sjukpenningförsäkringen byggde på inkomstbortfallsprincipen. Rent tekniskt sett skulle de sjukpenningförsäkrade placeras in i någon av tio sjukpenningklasser. Socialvårdskommittén motiverade tydligt sitt val av inkomstbortfallsprincipen. Bland annat sägs att behovet av kontant sjukhjälp står $\mathrm{i}$ viss proportion till den normala arbetsinkomsten, särskilt vid mera kortvariga sjukdomar. De försäkrades utgifter är nämligen, enligt kommittén, anpassade till deras normala inkomster och utgifterna kan som regel inte hastigt skäras ned vid inträffad sjukdom. Ej heller är det ur social synpunkt önskvärt att sjukdom skall förorsaka någon större standardförsämring. Hänsyn bör också tas till de regler som gäller inom den obligatoriska olycksfallsförsäkringen, och där tilllämpadesinkomstbortfallsprincipen. Sjukförsäkringen skulle finansieras genom egenavgifter och statsbidrag. Försäkringen utgick administrativt från de då existerande erkända sjukkassorna. Dessa skulle omvandlas till allmänna sjukkassor.

Socialvårdskommitténs förslag visar stora principiella likheter med 1919 års förslag. Båda bygger exempelvis på inkomstbortfallsprincipen. Den sistnämnda motiveras i båda fallen bland annat med hänvisning till en önskvärd samordning med olycksfallsförsäkringen. Vi finner också den intressanta likheten att man i båda förslagen räknar med att ungefär två tredjedelar av försäkringskostnaderna skall finansieras genom egenavgifter. De skillnader som finns sammanhänger väsentligen med den ekonomiska utveckling som skett och med under mellantiden tagna socialpolitiska beslut.

Efter remissbehandlingen av socialvårdskommitténs förslag påbörjades en omarbetning av detta inom socialdepartementet. Efter en ny remissomgång avlämnades en proposition, signerad av Gustav Möller, till 1946 års höstriksdag (Proposition 1946:312). Propositionen, som innehöll en i princip helt ny sjukförsäkringskonstruktion, antogs i allt väsentligt av riksdagen.

En viktig del i Möllers förslag var att sjukvården och ersättningen för läkemedel utmönstrades som sjukförsäkringsprestationer. Sjukvården skulle skattefinansieras och härigenom skulle sjukkassorna inte behöva befatta sig med dess prestationer.

Enligt Möller borde sjukpenningen utgå enligt minimistandardprincipen. Det av Möller föreslagna och senare av riksdagen antagna enhetsunderstödet uppgick till $3.50 \mathrm{kr} / \mathrm{dag}$, som var högre än sjukpenning i de lägsta klasserna i socialvårdskommitténs förslag. Valet av minimistandardprincipen är ett uttryck för Möllers 
socialpolitiska ideologi. Principen är, skriver han i propositionen "principiellt riktigast« i en obligatorisk sjukförsäkring (Proposition 1946:312, sid 136). Försäkringsskydd utöver existensminimum bör individen "av egen ansvarskänsla» själv svara för. Utöver denna principiella ståndpunkt följer också, enligt Möller, en administrativ förenkling med enhetsunderstödet. Den sjukkassemedlem som önskar en högre försäkringsersättning ges möjlighet att i sjukkassan frivilligt försäkra sig för tilläggssjukpenning.

En viktig nyhet i Möllers förslag följde av att källskattereformen blivit klar efter det att socialvårdskommittén avlämnat sitt betänkande. Avgifterna till den obligatoriska delen av försäkringen skulle nu uppbäras i samband med källskatten. Beträffande finansieringen råder en viktig principiell skillnad mellan Möller och socialvårdskommittén. I Möllers förslag betalar de försäkrade endast ca 25 procent $\mathrm{i}$ form av avgifter, resten är skattefinansiering.

Möllers uppfattning i samordningsfrågan framstår som oklar och han är i propositionen ej beredd att ta ställning. Det verkligt stora problemet är givetvis minimistandardprincipen, eftersom olycksfallsförsäkringen och arbetslöshetsförsäkringen utgick från en inkomstbortfallsprincip. I riksdagsdebatten säger han (med socialvårdskommittén som adressat) att "med litet organisatorisk och konstruktiv fantasi skall det visa sig lätt nog att finna vägar att verkligen samordna dessa socialförsäkringsgrenar" (Protokoll AK 1946:42, sid 13). Han nämner att man för olycksfallsförsäkringens del skulle kunna tillämpa samma minimistandard som sjukförsäkringen och härutöver en inkomstgraderad sjukpenning. Han avslöjar också att hans tanke wär att arbetslöshetsförsäkringen skall komma att utformas som en enhetlig försäkring med fri påbyggnad precis som sjukförsäkringen» (Ibid).

1946 års beslut var ett principbeslut och reformen skulle träda i kraft först 1950. Anledningen till denna fördröjning var dels att man avvaktade en kommunindelningsreform, dels att sjukvårdsresurserna måste byggas ut. Ett annat skäl till att ett principbeslut skulle tas redan 1946 var att detta skulle bli vägledande för socialvårdskommittén $i$ dess fortsatta arbete med olycksfallsförsäkring och arbetslöshetsförsäkring.

Remissinstanserna hade ställt sig i stort sett positiva till socialvårdskommitténs förslag. Möller gick emellertid sin egen väg och fick en kompakt riksdagsmajoritet på sin sida. Det är påtagligt att riksdagsdebatten var matt och att motståndet mot Möllers förslag var svagt. Möllers djärva lösning av sjukvårdsfrågan blev i stort sett allmänt accepterad.

Möllers konstruktion gynnade särskilt låginkomsttagare och, inte minst, landsbygdsbefolkningen. Sannolikt hade Möller stöd i den allmänna opinionen (Lindqvist 1990) och på det politiska planet fick han med sig nästan hela den socialdemokratiska riksdagsgruppen, kommunisterna, bondeförbundet samt delar av folkpartiet. Högern var en konsekvent motståndare och förordade en lösning motsvarande socialvårdskommitténs. 


\section{Olycksfallsförsäkringen}

Socialvårdskommittén avlämnade alldeles i början av år 1948 ett betänkande med förslag till vissa förändringar i olycksfallsförsäkringen. De föreslagna förändringarna sammanhängde med den pris- och lönehöjning som skett sedan krigsslutet. Det lägsta ersättningsbeloppet sattes till 3.50 kronor per dag, det vill säga samma belopp som i den beslutade obligatoriska sjukförsäkringen. Vidare föreslogs en rejäl höjning av maximiersättningen samt något bättre karensbestämmelser. Förbättringarna sågs som provisoriska i avvaktan på den grundligare utredning om yrkesskador och yrkessjukdomar som kommittén var i färd med att genomföra. Regeringen, det vill säga Gustav Möller, och riksdagen anslöt sig till förslaget (Proposition 1948:235).

Socialvårdskommittén kritiserade i sitt betänkande starkt den beslutade sjukförsäkringen. Enligt kommittén vore det i högsta grad önskvärt med en samordning mellan sjuk- och olycksfallsförsäkringarna. Man för fram fördelarna såsom snabbare sjukhjälpsutbetalningar till de drabbade, bättre sjukkontroll och en administrativ förenkling. Vidare menade man att olycksfallsförsäkringen inte borde omfatta åkommor av kort varaktighet eftersom prövningen av ersättningsfrågor ofta var mycket besvärlig.

\section{Omöjliga och möjliga refor- mer 1948-1951}

\section{Bakgrund}

Åren kring krigsslutet kännetecknades av en stor osäkerhet och desorientering om efterkrigstidens ekonomiska utveckling
(Lundberg 1983). Paralleller drogs med utvecklingen efter första världskriget och i orosbilden fanns möjligheten av en stor efterkrigsdepression. Nu uppstod ingen depression och i stället kom utvecklingen efter kriget att kännetecknas av en låg arbetslöshet, god tillväxt, höjda reallöner och inflationstendenser. Inflationstrycket följdes av den s.k. reformpausen 1948. Då hade stora socialpolitiska reformer som folkpensionen och barnbidrag genomförts och såväl socialdemokrater som de borgerliga ansåg att det då inte fanns utrymme för fler kostnadskrävande reformer. I den situationen blev Möllers, för statsverket relativt dyra, sjukförsäkring ifrågasatt.

År 1950 fick pensionsstyrelsen i uppdrag att göra nya kostnadsberäkningar för sjukförsäkringen. Samma år tillsattes den första s.k. långtidsutredningen. Till dess uppgifter hörde att belysa utrymmet för socialpolitiska reformer. I sitt betänkande, som publicerades 1951, behandlades därför sjukförsäkringen (SOU 1951:30). Med utgångspunkt i pensionsstyrelsens utredning, och i den förväntade samhällsekonomiska utvecklingen menade långtidsutredningen att genomförandet av obligatorisk sjukförsäkring var betingat av möjligheten att gå fram avgiftsvägen.

Möller hade tidigare anklagats för "ekonomiskt lättsinne» av finansminister Wigforss. I den nu kärva statsfinansiella situationen skärptes motsättningarna mellan främst finansministern (Wigforss och senare Sköld) och Möller (Andersson 1980, Jonasson 1976, Möller 1971, Ruin 1986). Möllers sista stora seger blev dyrtidstilläggen till folkpensionen. Möller hade 1946 avgivit ett löfte i riksdagen att före- 
slå ett dyrtidstillägg till folkpensionerna, då reformen skulle träda i kraft 1948, om prisutvecklingen så motiverade. Eftersom prisnivån stigit med fem procent begärde Möller i regeringen att få lägga en proposition om ett dyrtidstillägg om fem procent. I denna fråga fick Möller hela regeringen emot sig med Wigforss som den starke nejsägaren. I stället ingick Möller via bulvaner med en motion i frågan. Vid de fortsatta diskussionerna inom regeringen hotade Möller avgå om propositionen ej avlämnades. Man stannade inom regeringen för kompromissen att dyrtidstilläggen skulle utgå efter inkomstprövning. Riksdagen stödde motionslinjen!

\section{Arbetslöshetsförsäkringen}

Socialvårdskommittén avlämnade sitt betänkande om arbetslöshetsförsäkring hösten 1948 (SOU 1948:39). I betänkandet presenteras två förslag, alternativ I och alternativ II. Kommittémajoriteten förordade alternativ II. Båda förslagen innebar att en allmän obligatorisk arbetslöshetsförsäkring skulle införas.

En principiellt viktig fråga gällde om ersättningen skulle utgå med enhetsbelopp eller enligt inkomstbortfallsprincipen. Som tidigare nämnts hade socialvårdskommittén i sjukförsäkringsfrågan förordat den sistnämnda principen. Inom sjukförsäkringen, konstaterade man, hade riksdagen beslutat om enhetsersättning plus en möjlighet till statsunderstödd tilläggsförsäkring. Motsvarande konstruktion anser kommittén omöjlig för en arbetslöshetsförsäkring bland annat av det skälet att den enskilde har lättare att bedöma sin arbetslöshetsrisk än sin sjukrisk.
En frivillig statsunderstödd tilläggsförsäkring skulle därför tendera dra till sig "dåliga risker" varför avgiften fick sättas så högt att den blev prohibitiv. Kommitténs slutsats blev att ersättningen inom den obligatoriska arbetslöshetsförsäkringen borde inkomstrelateras.

Med en inkomstrelaterad ersättning följer en inkomstrelaterad avgift, vilken bör vara enhetlig för hela landet (för att möjliggöra riskutjämning). En samordningsvinst skulle kunna nås om avgiften uppförs på debetsedeln och sammanslås med bland annat avgifterna för folkpension och sjukförsäkring till en socialförsäkringsavgift. Detta kräver emellertid en ändring av sjukförsäkringen. Socialvårdskommittén föreslår att sjukförsäkringen omprövas och konstrueras i enlighet med inkomstbortfallsprincipen. Enligt 1946 års riksdagsbeslut skulle sjukkassorna uppbära sina egna avgifter och vara självförvaltande. Om man emellertid avstår från självförvaltningen är vägen fri till enhetlig sjukförsäkringsavgift och därmed också till en enhetlig socialförsäkringsavgift. Därmed bortfaller över huvudtaget skälet till att bibehålla sjukkassebenämningen. Man bör i stället inrätta lokala socialförsäkringsnämnder som svarar för samtliga socialförsäkringsgrenar.

Alternativ II, majoritetsförslaget, skiljer sig i ett fundamentalt avseende från alternativ I. Enligt alternativ II skulle de erkända kassorna finnas kvar, deras verksamhet skulle fortsätta i praktiskt taget oförändrade former, och nya kassor skulle få bildas. De som inte tillhörde en erkänd arbetslöshetskassa skulle tillförsäkras en enhetsersättning, som socialförsäkrings- 
nämnderna skulle administrera. Arbetslöshetskassorna skulle åtnjuta ett statsbidrag motsvarande enhetsersättningen samt ett statsbidrag för överskjutande dagersättning enligt i princip då gällande grunder.

Anledningen till att socialvårdskommittén utarbetade alternativet II är inte svår att finna. En försäkring som möjliggjorde ett bibehållande av de erkända arbetslöshetskassorna svarade mot fackföreningsrörelsens och speciellt då kassaförbundens intresse i arbetslöshetsförsäkringsfrågan. De erkända kassorna hade nått en aktningsvärd omfattning sedan 1941. Detta innebar rent allmänt att kassorna kunde få en viktig roll i en obligatorisk arbetslöshetsförsäkring men också att kassaförbundens politiska position stärktes. De fick ett växande inflytande dels genom sin år 1945 bildade samorganisation dels inom fackföreningsrörelsen (Edebalk 1990).

Socialvårdskommitténs betänkande publicerades under det s.k. reformstoppet. De starkaste intressenterna var dessutom, i stort sett, negativa till en obligatorisk arbetslöshetsförsäkring. Arbetslöshetskassornas samorganisation intog i sitt remissyttrande en bestämd ståndpunkt: förslagen till obligatorisk arbetslöshetsförsäkring bör avslås och i stället bör den frivilliga försäkringen effektiviseras. LO (dvs landssekretariatet) uttryckte i sitt remissvar en rad invändningar mot båda alternativen varför en överarbetning föreslås. Av 32 förbund som yttrat sig till landssekretariatet uttalade sig 22 mot en obligatorisk försäkring och för en utbyggd frivillig försäkring (Edebalk 1990). Ett av dessa var det stora metallindustriarbetareförbundet. TCO framhöll i sitt yttrande att det ur tjänstemännens synvinkel inte fanns behov av en obligatorisk arbetslöshetsförsäkring.

För Gustav Möller var det naturligtvis en komplikation att socialvårdskommitténs förslag förutsatte ett nytt sjukförsäkringsbeslut. Och att uppbåda en riksdagsmajoritet, som han varit så skicklig i tidigare, var knappast möjligt i då rådande läge. Dessutom hade Möllers ställning blivit försvagad inom regeringen. Hans sista seger blev dyrtidstillägen till folkpensionen 1948. Möllers avgångshot då samt riksdagsbeslutet kom före riksdagsmannavalet. Inom regeringen var man givetvis ytterst medveten om konsekvenserna om Gustav Möller avgått på en för stora grupper betydelsefull socialpolitisk fråga. Socialvårdskommitténs betänkande kom efter riksdagsmannavalet. Då blev Möllers situation svagare och då fanns ingen stark aktör som ville driva frågan om en obligatorisk arbetslöshetsförsäkring.

\section{Sjuk-och yrkesskadeförsäkringarna}

År 1948 beslutade riksdagen att uppskjuta ikraftträdandet av Möllers sjukförsäkringsreform till 1951 (Proposition 1948:308). Orsaken angavs vara att arbetet med kommunindelningsreformen ej fortgått enligt det uppgjorda schemat (den trädde sedan i kraft 1952). Dessutom angavs att det var platsbrist på sjukhusen och brist på sjuksköterskor och läkare. På våren 1950 deklarerade statsminister Erlander i riksdagen att det av statsfinansiella skäl var omöjligt att låta reformen 
träda i kraft 1951. Under hösten 1950 avlämnades en proposition som antogs av riksdagen (Proposition 1950:252). Beslutet innebar att reformen uppsköts tills vidare.

I efterkrigsmiljön fanns en rad aktörer i sjukförsäkringsfrågan. Tre politiskt betydelsefulla aktörer var socialvårdskommittén, sjukkasserörelsen och landsorganisationen. Socialvårdskommittén föreslog 1948 att sjukförsäkringsbeslutet skulle omprövas. Kommittén behandlade yrkesskadeförsäkringen (den då nya benämningen) i sitt allra sista betänkande 1951 (SOU 1951:25). Yrkesskadeförsäkringen skulle vara en genom arbetsgivaravgifter finansierad obligatorisk försäkring som omfattade yrkesskador och yrkessjukdomar. En samordning med sjukförsäkringen ansågs som högst önskvärd men på grund av sjukförsäkringsfrågans läge såg man sig förhindrad att göra ett samordningsförslag.

Sjukkasserörelsen, med sjukkasseförbundet i spetsen, fick i och med 1946 års riksdagsbeslut börja anpassa sig till den kommande reformen. Sjukkasserörelsens reaktion på socialvårdskommitténs förslag om socialförsäkringsnämnder 1948 blev, milt uttryckt, negativ. Nu kom det att handla om rörelsens överlevnad. Retad blev också sjukkasserörelsen över uppskovsbesluten 1948 och 1950 (Svensk sjukkassetidning 1948 och 1950). Förberedelsearbetet med sjukförsäkringsreformen hade varit i full gång och medlemsvården hade eftersatts (den nya försäkringen skulle ju bli obligatorisk). För sjukkasserörelsen framstod situationen år 1950 helt enkelt som kaotisk. Rörelsen börjar med emfas att kräva en återgång till socialvårdskommitténs sjukförsäkringsförslag, givetvis med tanke på finansieringsaspekten men också för att undanröja Möllers enhetsunderstöd.

LO hade inte visat något starkare sjukförsäkringsengagemang inför 1946 års riksdagsbeslut. LOs under efterkrigstiden alltmer positiva inställning till inkomstbortfallsprincipen inom sjukförsäkringen kan ses mot bakgrund av den ekonomiska utvecklingen. Men framför allt kom Möllers enhetsunderstöd att uppfattas som ett hinder för ytterligare förbättringar i skyddet för de yrkesskadade. Det växande samordningsintresset inom LO fick ett pregnant uttryck på 1951 års LO-kongress. Kongressen uttalade sig enhälligt för en samordning mellan sjuk- och yrkesskadeförsäkringarna och landssekretariatet formulerade det så i ett yttrande natt från fackföreningsrörelsens sida allt bör göras för att genomföra ett sådant system" (Kongressprotokollet, sid 386).

I den ekonomiska efterkrigsmiljön och med i denna verkande viktiga aktörsgrupper blev en sjukförsäkring à la Möller alltmer omöjlig. På det parlamentariska planet visade sig utvecklingen i uppskovspropositionen 1950 men också i höger- och folkpartimotioner (Motion $\mathrm{Fk}$ 1950:539 och Ak 1950:630). I dessa krävdes en omprövning av 1946 års beslut.

\section{Nya vindar}

Enligt en gallupundersökning 1950 var sjukförsäkringsreformen den reform som det svenska folket ansåg vara mest angelägen. Trycket på regeringen att handla var mycket starkt. Först då Gustav Möller 
ställts åt sidan efter tillkomsten av koalitionsregeringen hösten 1951 blev detta en reell möjlighet. Den nye socialministern Gunnar Sträng tillsatte snabbt en ny utredning, den s.k. socialförsäkringsutredningen. Samtidigt tillsattes en helt annan utredning med syfte att effektivisera den frivilliga arbetslöshetsförsäkringen. Här hade samorganisationen aktivt agerat.

Arbetslöshetsförsäkringsutredningen presenterade ett delbetänkande redan 1952. Detta låg till grund för en rejäl förstärkning av försäkringsförmånerna, något som en i stort sett enig riksdag beslutade 1953 (Proposition 1953:166). Detta beslut kom att ge en kraftfull stimulans till etablerandet av nya erkända arbetslöshetskassor. $\mathrm{Nu}$ var det inte längre tal om en obligatorisk arbetslöshetsförsäkring eller någon samordning mellan sjuk- och arbetslöshetsförsäkringarna.

Socialförsäkringsutredningen var färdig med sitt arbete inom ett år (SOU 1952: 39). Dess förslag kom i allt väsentligt att godtas av regering och riksdag. Reformen trädde i kraft 1955. Samordningsfrågan hade en central plats i utredningen och samordningstiden mellan sjuk- och yrkesskadeförsäkringarna föreslogs bli 90 dagar. Under denna tid svarar alltså sjukförsäkringen för ersättningen och det uppskattades att minst 90 procent av alla yrkesskadefall skulle ligga inom denna period. Härefter övertogs ersättningen till yrkesskadade av en föreslagen ny yrkesskadeförsäkring. Sjukförsäkringens prestationer utgörs av sjukpenning och sjukvård $\mathrm{i}$ likhet med socialvårdskommitténs modell och sjukpenningen utgår enligt inkomstbortfallsprincipen.
I sjukvårdsförsäkringen ingår bland annat sjukhusvård. Enligt Möller skulle fri sjukhusvård lämnas vid sidan av försäkringen. Sjukvårdsreformen måste införas samtidigt med sjukpenningreformen med tanke bland annat på samordningen med yrkesskadeförsäkringen. Att sjukhusvården nu förs in i sjukförsäkringen sammanhänger främst med statsfinansiella hänsyn. Sjukförsäkringens inkomster kommer från de försäkrade, arbetsgivarna och staten. De försäkrades egna avgifter beräknades svara för ca 45 procent och arbetsgivarna för ca 25 procent av de totala kostnaderna.

Socialförsäkringsutredningens förslag visar i sin uppläggning stora likheter med socialvårdskommitténs. Den största skillnaden gäller arbetsgivaravgifterna. Skillnaden torde helt bero på att socialförsäkringsutredningen lämnade ett konkret förslag till samordning, medan socialvårdskommittén talade om en önskvärd framtida samordning, det vill säga efter det att man även utrett yrkesskadeförsäkringen.

\section{Möllers socialförsäkringssyn \\ Modellen}

Gustav Möller var inte helt explicit beträffande det socialförsäkringssystem som skulle byggas upp efter andra världskriget. Två beslut togs, beträffande pensioner och sjukförsäkring, där hans tankegångar fullföljdes. Då det gäller arbetslöshetsförsäkring, olycksfallsförsäkring (yrkesskadeförsäkring) samt samordningsfrågorna får vi söka en rimlig tolkning. Det kan givet- 
vis vara så att Möller inte hade någon helt färdig modell vid krigsslutet; det kan också vara så att hans syn förändrades när de ekonomiska och politiska förutsättningarna ändrades under efterkrigstiden. Vi måste således vara medvetna om att det vi kallar »Möllers modell» är (eller kan vara) en rekonstruktion, en möjlig tolkning. Det material som ligger till grund för rekonstruktionen är riksdagshandlingar, Möllers Tidenartiklar och pamfletter samt Socialboken. Den sistnämnda utkom 1949 på Möllers initiativ. Boken har skrivits av den dåvarande unge tjänstemannnen vid socialdepartementet Ernst Michanek. Han skriver bland annat att Möller med stort intresse följt bokens tillkomst och många fall hjälpt mig över missuppfattningarna och feltolkningarnas fallgropar" (Michanek 1949, sid 14). I förordet skriver Möller bland annat att vi står vid slutet av en epok och att de uppgifter som finns i Socialboken kommer $\mathrm{i}$ allt väsentligt att "förbli giltiga under åratal framåtu (Michanek 1949, sid 9).

Socialförsäkringen skulle enligt Möller garantera en viss minimistandard för samtliga medborgare; dess idé var att ge trygghet mot nöd. Förmånerna skulle utgå som en medborgerlig rättighet och alltså inte vara beroende av tidigare inbetalda avgifter eller av myndigheters godtycke. Systemet skulle, i allt väsentligt, vara skattefinansierat och därigenom medvetet bidra till inkomstutjämning.

Huvudprincipen var att förmånerna skulle utgå som enhetsunderstöd. Alternativet inom en Möllermodell kunde vara inkomstprövade förmåner. Sådana kunde motiveras av statsfinansiella skäl och Möl- ler menade också inför pensionsbeslutet 1946 att han kunde bli tvingad att acceptera en sådan lösning (Möller 1946). Fördelarna med inkomstprövning var statsfinansiella och att förmånerna mer direkt kunde riktas till låginkomsttagare. För Möller var emellertid inkomstprövningen det näst bästa alternativet. Med ett enhetsunderstöd blev administrationen enklare och folk blev inte frestade att uppge felaktiga inkomster. Möller vände sig också emot, liksom många andra debattörer, att inkomstprövade förmåner ger negativa incitament för arbete och sparande. I vissa fall lyckades det ej att genomföra ett enhetsunderstöd. Detta gäller exempelvis den invalidpension som beslutades samtidigt som ålderspensionen.

En ersättning enligt minimistandardprincipen förutsätter kompletteringar. För det första så är enhetsersättningens realvärde skiftande geografiskt sett. Under 1930-talet genomdrev Möller därför dyrortsgraderade pensioner. Dyrortsgraderingen försvann med 1946 års beslut och i stället infördes bostadsbidrag till pensionärerna (framför allt hyreskostnaderna var olika i till exempel storstäder och glesbygd). På motsvarande sätt kan den frivilliga påbyggnaden inom sjukförsäkringen ses som en möjlighet att kompensera för skilda levnadskostnader. För det andra förutsätts kompletteringar på grund av skiftande försörjningsbördor. I Möllers modell finns därför hustrutillägg och barntillägg.

Folkpensionen och sjukförsäkringen ger konkreta exempel på Möllers socialförsäkringssyn. Frågan är hur olycksfallsförsäkringen passade in i systemet. Det 
finns inga belägg för att Möller ansåg att olycksfallsersättning skulle utgå med enhetsunderstöd eller att denna skulle skattefinansieras. Att olycksfall (yrkesskador) skulle ses som en del av produktionskostnaderna, och att arbetsgivarna alltså skulle betala avgifterna, har knappast ifrågasatts i Sverige under 1900talet. Eftersom ersättningen ansetts ha karaktär av skadestånd har ej heller inkomstbortfallsprincipen, som infördes 1916, varit ifrågasatt. Möllers uppfattning om olycksfallsförsäkringen torde väl stämma överens med 1948 års riksdagsbeslut där lägsta ersättning svarade mot sjukförsäkringens enhetsersättning. Möller menade för övrigt att den svenska olycksfallsförsäkringen i och med 1948 års beslut var främst i världen (Möller 1948).

Olycksfallsförsäkringen skulle vara en separat försäkring utanför grundtrygghetssystemet. Hur skulle den koordineras med sjukförsäkringen? Här finns åtminstone tre möjligheter. Den första är att sjukförsäkringen tar hand om den första tiden av ett olycksfall (eller yrkessjukdom). Detta vore emellertid en orealistisk lösning. Här skulle i så fall skattebetalarna i gemen få finansiera större delen av alla arbetsskador och det skulle bli en rejäl privatekonomisk försämring för de olycksfallsdrabbade. Att Möller skulle vara beredd att försämra "världens bästai olycksfallsförsäkring finns inga belägg för.

Den andra lösningen vore att sjukkassorna enbart administrerar olycksfallsförsäkringen. Detta skulle innebära att den enskilda sjukkassan hade att betala olika ersättningar (dvs till sjukförsäkrade respektive olycksfallsförsäkrade) och det skulle bli ett knivigt utredningsarbete även vid obetydliga arbetsskador. Med en sådan lösning skulle poängen med samordning försvinna och några administrativa inbesparingar skulle knappast bli följden.

Den tredje möjligheten är att någon samordning ej skulle ske (bortsett från själva minimiersättningen). Detta är den möjlighet som är mest realistisk $i$ ett Möllersystem. Det antyds för övrigt också i Socialboken.

Möllers uppfattning om arbetslöshetsförsäkringen framgår under 1946 års riksdagsdebatt: en enhetlig försäkring med fri påbyggnad precis som sjukförsäkringen. I en Tidenartikel 1952, alltså efter hans avgång som socialminister, skriver han att fackförbunden är "mycket ljumt intresserade" av en obligatorisk arbetslöshetsförsäkring som skulle förvaltas av offentliga organ (Möller 1952, sid 393). Detta skall ses som en illustration till att Möller själv önskade en obligatorisk försäkring. Det är emellertid uppenbart att arbetslöshetsförsäkringen som sådan blev förhållandevis ointressant för Möller med det goda sysselsättningsläge som rådde efter krigsslutet. I en artikel i Tiden 1947 skrev han till exempel att han inte betraktade arbetslöshetsförsäkringen som en av »de bärande socialpolitiska pelarna" och att en sådan försäkring endast "tillfälligtvis och i enstaka fallı skulle behöva tas i anspråk i fullsysselsättningssamhället (Möller 1947, sid 342).

Arbetslöshetsförsäkringen skulle vara allmän och obligatorisk och eftersom den definitionsmässigt enbart omfattade förvärvsarbetande borde arbetsgivarna bidra 
till försäkringen. Här föreligger alltså en skillnad från sjukförsäkringen. Frågan är då hur en frivillig påbyggnad skulle se ut. Att organisera den på samma sätt som sjukförsäkringen skulle ge märkliga incitament, något som Möller säkert var medven om. En sådan försäkring skulle te sig särskilt gynnsam för dem som arbetar inom områden med förhållandevis hög arbetslöshetsrisk. Härigenom skulle försäkringen riskera få ett ofördelaktigt urval (s.k. adverse selection).

Mer realistiskt, speciellt med tanke på de fackliga arbetslöshetskassornas utveckling och ställning, vore att den frivilliga påbyggnaden ombesörjdes av de fackliga organisationerna. Man kan här tänka sig två varianter. Grundförsäkringen administreras av ett särskilt organ som kan vara ett allmänt socialförsäkringsorgan eller de beslutade sjukkassorna. Härutöver kommer de fackliga arbetslöshetskassorna. Alternativt kan arbetslöshetskassorna handha även enhetsunderstödet för sina medlemmar medan de som ej var kassamedlemmar hade att vända sig till det allmänna socialförsäkringsorganet (eller sjukkassan).

Arbetslöshetsförsäkringens ställning i Möllers system syns problematisk. Antingen ger lösningen en påtaglig möjlighet till "ofördelaktigt urval" eller så uppstår en dubbeladministration. En rimlig tolkning är att Möller vid krigsslutet lutade år "sjukförsäkringslösningen". Hans explicita riksdagsyttrande liksom exempelvis socialvårdskommitténs häftiga anfall på denna konstruktion tyder på detta. Lika rimligt torde det vara att han, eftersom arbetslöshetsförsäkringens sociala och po- litiska betydelse reducerades, kom att acceptera socialvårdskommitténs majoritetsförslag.

Den administrativa samordningen av socialförsäkringssystemet hade engagerat Möller redan på 1920-talet. I en broschyr år 1926 skrev han att sjukkassan skulle vara en slags moderorganisation för de övriga socialförsäkringsgrenarna (Möller 1926). De lokala monopolsjukkassor som han ville se (det var de kassor som senare bildades 1931) skulle skapa den lokala grundorganisationen som behövdes för hela socialförsäkringen. Samma ståndpunkt förde han fram i ett valprogram 1928 (Möller 1928) och i riksdagen. I exempelvis riksdagsdebatten inför 1931 års sjukförsäkringsbeslut menade han att ett viktigt skäl för en reform var att en enhetligt organiserad sjukkasserörelse skulle ge grundvalen för det sociala försäkringssystemet (Protokoll Fk 1930:38).

Möller var alltså en tidig förespråkare för en enhetlig socialförsäkringsorganisation. Enligt de två riksdagsbesluten 1946 skulle det finnas sjukkassor och pensionsnämnder. Dessa lokala organ var man tvungen att fatta beslut om så att reformarbetet kunde påbörjas. Pensionsbeslutet skulle ju träda i kraft 1948. Den till synes konsekventa lösningen, med syftet att få enhetlighet och samordning, torde vara socialvårdskommitténs förslag till lokala socialförsäkringsnämnder. Detta organ som särskilt omnämns i Socialboken, skulle handha socialförsäkringarna utom olycksfallsförsäkringen. Förslaget, och detta påpekas särskilt i Socialboken, innebär att pensionsnämnderna och lokalsjukkassorna försvinner som självständiga or- 
gan. Detta skulle också innebära att en för folkpensioneringen, sjuk- och arbetslöshetsförsäkringen gemensam socialförsäkringsavgift skulle upptas i samband med skatteuppbörden (Michanek 1949).

Att socialförsäkringsnämnder ingår som lokala organ i Möllers system syns uppenbart och särskilt anmärkningsvärt är det att lokalsjukkassorna skulle försvinna. Det var ju en tanke från 1920-talet att enhetssjukkassorna skulle utgöra moderorganisationen. Om fler socialförsäkringsgrenar läggs i moderorganisationen blir denna, definitionsmässigt, inte längre en sjukkassa utan en socialförsäkringskassa. Det finns en rad andra omständigheter som indikerar att Möller ville ha bort lokalsjukkassorna. Sjukkasserörelsen hade protesterat kraftfullt mot socialvårdskommitténs organisationsförslag men detta till trots vågade Möller utmana sjukkasseintressenterna i Socialboken. Vidare hade socialvårdskommitténs ordförande, Bernhard Eriksson, tillsammans med två andra ledamöter, reserverat sig mot kommitténs förslag om socialförsäkringsnämnder (SOU 1948:39, sid 455). De lokala sjukkassorna borde finnas kvar som självständiga organ och sjukkassorna skulle också administrera arbetslöshetsförsäkringens enhetsersättning för dem som stod utanför fackliga kassor. Denna möjlighet nämns överhuvudtaget inte i Socialboken.

\section{Möllers självständighet}

Gustav Möller hade höga socialpolitiska ambitioner. Då reformer skulle genomföras eller hade beslutats hänvisade han ofta till utländska system. Han valde de bästa som fanns ute i världen antingen för att få draghjälp eller för att visa att de svenska lösningarna helt enkelt var bäst. Då det gällde folkpensionen, 1948 års olycksfallsförsäkring och 1946 års sjukförsäkring ställde sig Sverige främst i världen enligt Möller (Möller 1948).

Möller var också en stark politiker, "van att bestämma självu som Tage Erlander uttryckte det (Erlander 1974, sid 246). Hans styrka framgår i sjukförsäkringsfrågan då han körde över socialvårdskommittén, sjukkasserörelsen och praktiskt taget alla remissinstanser. I pensionsfrågan drev han igenom sin linje trots motstånd inom regeringen både 1946 och 1948 (dyrtidstillägget).

Möllers modell var universell, det vill säga öppen för alla medborgare då ett behov föreligger utan annat hänsynstagande till individen än att försäkra sig om att behovet föreligger. Om så är fallet har individen en rätt till en i förväg given ersättning. Just det universella draget var emellertid inte unikt inom svensk socialförsäkring. 1913 års pensionsförsäkring var världens första s.k. folkförsäkring, 1916 års olycksfallsförsäkring omfattade i princip hela arbetsmarknaden och 1919 års sjukförsäkringsförslag utgick från en allmän sjukförsäkring. Principen om en universell, eller generell, socialförsäkring hade alltså etablerats redan på 1910-talet.

Det verkligt unika i Möllers modell var minimistandardprincipen och tyngdpunkten på skattefinansiering. Förmånerna skulle utgå som en medborgerlig rättighet. Den svenska folkpensionen från och med 1948 anses för övrigt som det internationellt sett bästa exemplet på en social rät- 
tighet knuten till medborgarskap (Kohl 1993). Per Nyström (1983) hävdar att Möller i sin socialpolitiska syn varit starkt influerad av danskarna Bramsnaes och Steincke. I den mer konkreta utformningen av socialförsäkringen torde Steincke haft betydelse. Redan 1912 författade han skriften Almisser eller Rettigheder där han kritiserade det dåtida danska trygghetssystemet. I korthet menar Steincke att en rättighetsprincip borde ersätta den dåvarande allmose- och barmhärtighetsprincip som genomsyrade sociallagstiftningen. Medborgaren skall i lag ha rätt till vissa bestämda ersättningar då behov föreligger och i Sidney Webbs anda gäller denna rättighet "det sociale minimum". Ersättningarna skall vara skattefinansierade och alltså inte betingade av om avgifter erlagts. Steincke vidareutvecklade sina synpunkter $i$ en stor utredning 1919 och denna kom i allt väsentligt att ligga bakom den stora danska socialreformen 1933. Då var Steincke socialminister och den drivande kraften (Jonasen 1990). Socialreformen i Danmark blev internationellt uppmärksammad på grund av det helhetsgrepp som togs på det danska socialförsäkringssystemet.

Danmark sågs i mångt och mycket som ett föregångsland inom socialförsäkringar under mellankrigstiden och Möller hänvisade ofta till Danmark i tal och skrift (Elmér 1958, Möller 1926, 1928 och 1936). I den av Möller utformade pensionsmotionen 1928 nämns den skattefinansierade danska ålderspensionen som föredömlig. Frågan är emellertid i vad mån vi kan spåra eventuell påverkan av Steincke i Möllers socialförsäkringsmodell efter andra världskriget.

Steinckes tidiga förslag och socialreform i Danmark skall bland annat ses i ljuset av den ekonomiska och politiska situation som då rådde. En strikt medborgarrättsprincip, dvs skattefinansiering av på förhand givna ersättningar, gällde egentligen bara för ålders- och invalidpensionen. Arbetslöshetsförsäkringen och sjukförsäkringen administrerades av sedvanliga arbetslöshets- och sjukkassor. Sjukförsäkringen var obligatorisk endast för mindre bemedlade. I sjukkassornas förmåner ingick bland annat fri sjukhusvård. Olycksfallsförsäkringen var fristående och var samordnad på så sätt att sjukkassan betalade ersättning de första 13 veckorna (en icke sjukförsäkrad fick således ej ersättning under denna tid).

Det är säkert så, som Per Nyström skriver, att Möller var påverkad av Steincke. Vi finner två tydliga likheter mellan de båda: de hyste starka aversioner mot fattigvården och dess rättsverkningar och de hävdade att sociala ersättningar skulle utgå med på förhand bestämda belopp. Ersättningarna baserades på medborgarrätt och skulle väsentligen skattefinansieras. Detta torde vara Steinckes eventuella betydelse för Möller. I övrigt är Möllers system mer ambitiöst än Steinckes och de konkreta skillnaderna är påtagliga: Möllers pensioner är enhetsersättningar medan Steinckes är inkomstprövade (av statsfinansiella skäl). Möllers sjukförsäkring omfattar hela folket och sjukhusvården är utbruten. En möjlig tolkning, om vi följer Per Nyström en bit på vägen, kan vara att Möller konsekvent sökte genomdriva Steinckes rättsprincip, något som hade 
kunnat vara möjligt i Sverige efter andra världskriget men knappast i Danmark på 1910-talet eller omkring 1930.

Som tidigare nämnts hänvisade Möller under mellankrigstiden ofta till förhållandena i Danmark. Efter andra världskriget är det främst engelska förhållanden som Möller jämförde sina förslag med. Det engelska socialförsäkringssystem som höll på att ta form efter krigsslutet byggde på den s.k. Beveridgerapporten (Beveridge 1942). Denna är sannolikt det mest uppmärksammade socialpolitiska reformförslag som någonsin presenterats.

Det socialförsäkringssystem som William Beveridge presenterade 1942 innehöll följande huvudbeståndsdelar:

1) Socialförsäkringen skall vara allmän och obligatorisk. Den skall ge ersättning vid arbetslöshet, ålderdom, sjukdom och olycksfall (arbetsskada).

2) Prestationerna skall utgöras av kontantersättningar. Inom sjukförsäkringen ingår alltså inte läkar- och sjukhusvård. För varje medborgare skall läkar- och sjukhusvården vara fri, dvs skattefinansierad.

3) Kontantersättning utgår med enhetsunderstöd enligt minimistandardprincipen. Socialförsäkringens syfte, enligt Beveridge, är att garantera existensminimum. Ersättningen för olycksfall i arbete bakas in i den allmänna försäkringen men kompletteras med en särskild försäkringsform för speciellt farliga industrier. Vid olycksfall utgår kontant sjukhjälp under de 13 första veckorna och härefter en inkomstrelaterad invalidpension.

4) För finansieringen används arbets- givaravgifter, de försäkrades avgifter och skatter. Avgifterna är enhetsavgifter med undantag för riskdifferentierade arbetsgivaravgifter till olycksfallsförsäkringen.

5) För hela socialförsäkringen skall det finnas en gemensam statlig administration med lokalkontor.

Beveridgeplanens djärva samlade grepp på socialförsäkringsfrågan, och detta vid en tidpunkt då man kunde skönja en begynnande fredsoptimism, kan nog förklara den publicitet som rapporten fick och det intresse den väckte (Evans-Glennerster 1993, Hill 1990). Man kan emellertid lätt konstatera att Beveridgeplanen inte satt några synbarliga spår i socialvårdskommitténs förslag. Den enda likhet man finner är uppfattningen att socialförsäkringen skall vara allmän och obligatorisk. Beveridgeplanen byggde på en brittisk tradition i vilken det ingick enhetsunderstöd och en tredelad finansiering.

Beveridgeplanen fick ett starkt inflytande på Möller. På Möllers uppdrag utgavs exempelvis 1943 en fyllig skrift på svenska om planen (Larsson 1943). Och i sjukförsäkringsdebatten 1946 hänvisade Möller till att engelsmännen höll på att införa ett sjukförsäkringssystem av ungefär samma typ som det svenska (Protokoll Fk 1946:42). Även i övrigt finner vi hänvisningar till och jämförelser med England, ett land som Möller för övrigt besökte strax efter krigsslutet. En viktig likhet ligger $i$ användandet av minimistandardprincipen; detta var då förhållandevis ovanligt internationellt sett. Just beträffande sjukförsäkringen, där ju Möller kraftfullt drev en egen linje, är över- 
ensstämmelsen med Beveridgeplanen tydlig.

Det finns också en tydlig likhet beträffande ålderspensionen. Här kan ha funnits en påverkan från Beveridge, men några faktorer talar för att ålderspensionsbeslutet år 1946 kan förklaras utan hänvisning till Beveridge. Förslaget kom 1945 från socialvårdskommittén som året före i sitt sjukförsäkringsförslag visat sitt oberoende av Beveridge. Det politiska parti som först anslöt sig till enhetspensionen var högern, som stödde inkomstbortfallsprincipen för de övriga socialförsäkringsgrenarna. Vidare pekar den av Möller utarbetade motionen från 1928 fram mot en kommande folkpension.

Det fanns emellertid skillnader mellan Beveridge och Möller. Beveridge hade t.ex. lämnat en helhetslösning medan Möller tillämpade en steg-för-steg strategi. En helt avgörande skillnad mellan Beveridge och Möller gäller fördelningsambitionen. I Beveridgemodellen sker finansieringen av enhetsersättningarna genom enhetsavgifter och några fördelningsambitioner, bortsett från kategorier som sjuka/friska eller arbetslösa/sysselsatta finns knappast. Den svenske socialdemokraten och den brittiske liberalen konstruerade alltså sina system utifrån helt olika fördelningsönskemål.

För Beveridge, men ej för Möller, var avgifter en principiellt viktig del av systemet. Medborgarna ansågs föredra avgifter eftersom sådana skulle ge en säkrare rätt än enbart skattefinansiering. Avgiften skulle inte minst utgöra en restriktion för efterfrågan på högre utgifter. Med skattefinansiering skulle, enligt Beveridge, med- borgarna kunna förledas betrakta staten som en utdelare av gåvor för vilka ingen behöver betala.

\section{Enhetsunderstödet}

Beveridge och Möller förordade minimistandardprincipen och ännu en likhet mellan de båda är rent språkligt. Beveridge använde uttrycket "Freedom from want" och Möller "Frihet från nöd" för att markera syftet med principen. Deras modeller var mer försörjningssystem än försäkringar.

Ett enhetsunderstöd baserat på minimistandardprincipen förutsätter vissa kompletteringar. Hänsyn måste exempelvis tas till levnadskostnadernas geografiska fördelning. Möller kompletterade folkpensionen med bostadsbidrag, en lösning som inte fanns i Beveridgeplanen. Den frivilliga påbyggnaden i sjukförsäkringen hade också som syfte att möjliggöra högre ersättningar där levnadskostnaderna var högre. Vidare kräver minimistandardprincipen hänsyn till familjeförutsättningar och i Möllers system fanns exempelvis hustrutillägg och barntillägg.

Möllers enhetsunderstöd, liksom Beveridges, var nominellt givet. Detta gjorde systemet ytterst känsligt för inflation. Möllers egen uppfattning kring krigsslutet var att priserna skulle falla då världshandeln kom i gång på allvar. Han motsatte sig därför en indexreglering av folkpensionen. Inflationsutvecklingen och svårigheterna att genomföra dyrtidstillägget 1948 fick Möller att tänka om och förorda någon form av indexering.

Möller, liksom Beveridge, utgick från 
att i stort sett full sysselsättning skulle råda efter kriget. Med full sysselsättning följer emellertid visst inflationstryck och stigande nominella löner. I en inflationsekonomi ger inkomstbortfallsprincipen ett mer eller mindre automatiskt samband mellan nominella löner och ersättningar. I en inflationsekonomi vidgas gapet mellan nominella löner och enhetsunderstödet. "Fallhöjden" vid exempelvis sjukdom ökar och därmed försvåras den ekonomiska omställningen för den enskilde. Även relationen mellan olycksfallsförsäkringens ersättning (enligt inkomstbortfallsprincipen) och sjukförsäkringens förskjuts till den senares nackdel.

I efterkrigstidens Sverige kom alltså Möllers socialförsäkringssystem att te sig alltmer otidsenligt. Härtill kom problematiken kring yrkessjukdomar och den (i realiteten) omöjliga samordningen mellan sjuk- och olycksfallsförsäkringen. Under efterkrigstiden skedde bland annat en utvidgning av begreppet yrkessjukdom. Många av de sjukdomar som arbetare drabbades av kunde ses som en följd av arbetsprocessen, exempelvis rygg-och nervsjukdomar, utan att de i lagens mening betraktades som yrkessjukdomar. Detta innebar att olika yrkessjukdomar kunde få helt olika ekonomiska konsekvenser för den enskilde. En samordning mellan yrkesskade-och sjukförsäkringarna skulle under samordningstiden undanröja detta problem och ersättningen till den enskilde skulle ge en kompensation för bortfallen inkomst antingen det rörde sig om en "vanlig" sjukdom eller yrkessjukdom. Härtill kom att den enskilde under samordningstiden skulle få täckt sitt in- komstbortfall direkt utan att behöva visa, och inte sällan tvista om, att det var fråga om olycksfall eller yrkessjukdom.

Det socialförsäkringssystem som med stor kraft utvecklades i Sverige efter Möllers avgång byggde på inkomstbortfallskompensation. Olika socialpolitiska författare har hävdat att övergången till denna princip sammanhängde med en förändrad klasstruktur, bland annat genom: tjänstemannarörelsens utveckling (Lindqvist 1990, Marklund 1982). Här finns givetvis ett tidsmässigt samband. Det skall emellertid observeras att inkomstbortfallsprincipen som sådan blev knäsatt redan på 1910-talet. I 1901 års lag om ersättningsplikt ingick ett enhetsunderstöd. Då 1916 års olycksfallsförsäkringslag togs var man klar över att om hela arbetsmarknaden skulle omfattas (t.ex. välbetalda tjänstemän eller yrkeslärda arbetare) så blev en låg enhetsersättning ointressant. Vi vill därför här hävda att inkomstbortfallsprincipen som idé hänger i mångt och mycket samman med systemets omfattning. Att socialförsäkringen skulle vara universell och dessutom legitim implicerade en inkomstbortfallsprincip. Detta understryker än en gång det unika med Möllers enhetsunderstöd.

Möller motiverade sitt system bland annat med att det skulle skapa ett starkt samhälle, där medborgarna sammansvetsas till en solidarisk enhet. Engelska radikala forskare kom tidigt att kritisera Beveridgeplanens enhetsunderstöd och bana väg för inkomstbortfallsprincipen i England (Baldwin 1990, Heclo 1974). Vi finner här namn som Titmuss, Abel-Smith och Townsend. En del av kritiken gällde 
att enhetsunderstödet bidrar till att skapa "två nationeru: vissa medborgare erhåller ersättningar som ligger kring existensminimum, andra får högre ersättningar genom avtalslösningar eller privata försäkringar. Även moderna forskare har pekat på sådana effekter (Kangas 1991).

En annan kritik mot enhetsunderstöd, som ligger nära de engelska forskarnas, innebär att enhetsunderstödet skapar en dubbel administration (genom de kompletterande arrangemangen) och ett totalt trygghetssystem som blir mer svåröverskådligt för den enskilde (Ds 1989:68).

Under senare år har Möllers socialpolitiska synsätt uppmärksammats i olika sammanhang. Inte minst hans negativa syn på lösningar som föder en stor byråkrati har uppmärksammats. En enhetsersättning skulle, enligt Möller, innebära en administrativ förenkling (Möller 1946). När det gäller att värdera Möllers syn på byråkrati och ersättningsprincip måste man emellertid också se till administrativa konsekvenser i övrigt. Möllers argument för enhetsunderstödet är bestickande men åtminstone tre punkter förtjänar uppmärksamhet:

1) Möllers enhetsersättning krävde kompletteringar i form av hustrutillägg och dylikt. Detta innebär att en rad andra bakgrundsvariabler än inkomst måste redovisas.

2) För sjukförsäkringen, där ju beslut togs, infördes en frivillig tilläggsförsäkring utöver enhetsunderstödet. Detta skulle leda till en dubbeladministration inom sjukkassorna (eftersom enhetsunderstödet skulle finansieras källskattevägen). Om man dessutom antar att den frivilliga försäkringen skulle blivit framgångsrik (och detta vore väl socialt önskvärt) blir den administrativa vinsten tveksam. I övrigt gäller, generellt sett, att enhetsersättningar kan skapa dubbeladministration genom framväxten av kompletterande försäkringsarrangemang.

3) I Möllers modell ingick (med all sannolikhet) en utbruten yrkesskadeförsäkring. Detta skulle ha inneburit en stor administrativ komplikation och inte minst besvärligheter för den enskilde. Modellen skapade dessutom incitament att få skador och sjukdomar prövade som yrkesskador och yrkessjukdomar.

Minimistandard som vägledande princip inom svensk socialförsäkring hade förkastats redan på 1910-talet. Med Möller fick principen förnyad aktualitet strax efter andra världskriget. Möllers modell blev emellertid ej fullbordad. Kortsiktigt fördröjdes och hindrades den främst av kravet på några års förberedelsetid och härefter främst av statsfinansiella skäl. Modellen passade emellertid ej heller in i en mer långsiktig utveckling. Man vågar påstå att även om modellen skulle ha trätt i kraft hade den knappast förutsättningar att bli långlivad. Den ekonomiska tillväxten samt ett successivt växande intresse för frågor kring arbetsmiljö och yrkessjukdomar är här viktiga betingelser.

Under arbetet med artikeln har jag fått synpunkter på innehållet av Staffan Blomberg, Åke Elmér, Lars Harrysson, Ove Mallander, Paul Nystedt, Gunnar Olofsson, Jan Petersson och Eskil Wadensjö. Till dessa riktas ett varmt tack. 


\section{Referenser}

Andersson, Sven (1980): På Per Albins tid, Stockholm: Tiden

Beveridge, William (1942): Social Insurance and Allied Services, London: HMSO

Baldwin, Peter (1990): The Politics of Social Solidarity. Class Bases of the European Welfare State 1875-1955. Cambridge: Cambridge University Press

Ds 1989:68: Arbetsmarknadsförsäkringar, Rapport till expertgruppen för studier i offentlig ekonomi. Stockholm: Allmänna förlaget

Ds 1993:51: Social Security in Sweden and Other European Countries -Three Essays, Rapport till expertgruppen för studier i offentlig ekonomi. Stockholm: Allmänna förlaget

Edebalk, Per Gunnar (1975): Arbetslöshetsförsäkringsdebatten - en studie i svensk socialpolitik 1892-1934, Lund: Ekonomisk-historiska institutionen

Edebalk, Per Gunnar (1990): Från motstånd till genombrott. Den svenska arbetslöshetsförsäkringen 1935-54. Arkiv 45: 43-67

Edebalk, Per Gunnar (1993): 1916 års olycksfallsförsäkring. En framtidsinriktad socialpolitik. Scandia 1:113-134

Elmér, Åke (1958): "Danmark i den svenska folkpensionsdebatten" i Festskrift til Fredrik Zeuthen. København

Elmér, Åke (1960): Folkpensioneringen i Sverige. Lund: CWK Gleerup

Eriksson, Bernhard (1944): "Socialförsäkring och social omvårdnadı i Ett genombrott. Den svenska socialpolitiken. Utvecklingslinjer och framtidsmål, Stockholm: Tiden

Evans, M. \& Glennerster, H. (1993): Squaring the Circle? The Inconsistencies and Constraints of Beveridge's Plan, Discussion Paper WSP/86, London: London School of Economics

Erlander, Tage (1974): 1949-1954. Stockholm: Tiden

Heclo, Hugh (1974): Modern Social Politics in Britain and Sweden. From Relief to Income Maintenance, New Haven and London: Yale University Press
Hermansson, J. \& Svensson, T. (1989): «Möller och socialpolitikens principfrågorı Tiden 1:60-65

Hill, Michel (1990): Social Security Policy in Britain, Worcester: Edward Elgar

Jonasen, Viggo (1990): Dansk Socialpolitik 17081990, Århus: Den sociale höjskole

Jonasson, G. (1976): Per Edvin Sköld 1946-1951, Uppsala: Almqvist \& Wiksell

Kangas, Olli (1991): The Politics of Social Rights. Stockholm: Swedish Institute for Social Research

Kangas, O. \& Palme, J. (1989): Public and Private Pensions: The Scandinavian Countries in a Comparative Perspective, Stockholm: Institutet för Social Forskning

Kohl, Jürgen (1993): „Minimum Standards in Old Age Security and the Problem of Poverty in Old Age» i Atkinson A. B. \& Rein M. (eds): Age, Work and Social Security. New York: St. Martin's Press

Larsson, Sven (1943): Beveridgeplanen i sammandrag, Stockholm: Tiden

Lewin, Leif (1967): Planhushaillningsdebatten. Uppsala: Statsvetenskapliga föreningen

Lindblom, P. \& Jönsson, N-C (1986): Politik och kärlek, Stockholm: Tiden

Lindqvist, Rafael (1990): Från folkrörelse till välfärdsbyråkrati, Lund: Arkiv

Lundberg, Erik (1983): Ekonomiska kriser förr och $n u$, Stockholm: SNS

Landsorganisationen i Sverige (1951): 14:e ordinarie kongressen 8-15 sept. 1951. Protokoll. Stockholm

Marklund, Staffan (1982): Klass, stat och socialpolitik, Lund: Arkiv

Michanek, Ernst (1949): Socialboken, Stockholm: Tiden

Möller, Gustav (1926): Arbetslöshetsförsäkringen jämte andra sociala försäkringar, Stockholm: Tiden

Möller, Gustav (1928): Trygghet och säkerhet för Sveriges folk, Stockholm: Tiden

Möller, Gustav (1936): Bättre folkpensioner, Stockholm: Tiden 
Möller, Gustav (1946): De planerade socialreformerna, Tiden 2:70-85

Möller, Gustav (1947): Kan trygghet skapas? Ti$\operatorname{den} 6: 325-343$

Möller, Gustav (1948): Från Fattighus-Sverige till Social-Sverige, Stockholm: Tiden

Möller, Gustav (1952): Svensk socialpolitik. Tiden 7:391-399

Möller, Gustav (1971): „Hågkomster» i Wedin, $\AA$. (red): Arbetarrörelsens årsbok, Stockholm: Arbetarrörelsens arkiv

Nyström, Per (1983): I folkets tjänst. Historikern, journalisten och ämbetsmannen, Stockholm: Ordfronts förlag

Ohlin, Bertil (1975): Bertil Ohlins memoarer 1940-1951. Socialistisk skördetid kom bort, Stockholm: Bonniers

Olsson, Sven E. (1990): Social Policy and Welfare State in Sweden. Lund: Arkiv

Rothstein, Bo (1984): Gustav Möller, välfärdsstaten och friheten. Tiden 10:599-605

Rothstein, Bo (1987): Att administrera välfärdsstaten: några lärdomar från Gustav Möller. Arkiv nr 36-37:68-84

Ruin, Olof (1986): I välfärdsstatens tjänst. Tage Erlander 1946-1969, Stockholm: Tiden
SOU 1922:59: Betänkande och förslag angående offentlig arbetsförmedling och statsbidrag till arbetslöshetskassor

SOU 1925:8: Betänkande med utredning och förslag angående socialförsäkringens organisation

SOU 1934:18: Betänkande med förslag rörande revision av den allmänna pensionsförsäkringen

SOU 1944:15: Utredning och förslag angående lag om allmän sjukförsäkring

SOU 1948:39: Utredning och förslag angaiende lag om obligatorisk arbetslöshetsförsäkring

SOU 1951:30: Ekonomiskt långtidsprogram 195155

SOU 1952:39: Sjukförsäkring och Yrkesskadeförsäkring

Steincke, K. K. (1912): Almisser eller Rettigheder, København og Kristiania: Gyldendelske Boghandel

Steincke, K. K. (1920): Fremtidens Forsørgelsevaesen, København: Indenrigsministeriets Foranstaltning

Svensk sjukkassetidning, olika årgångar

\section{Summary Möller's Modell of Swedish Social Insurance 1944-51}

Gustav Möller was Minister of Health and Social Affairs in Sweden for most of the period 1932-51. He was a social democrat and an independent, strong politician in the field of social affairs. After World War II, the system of social insurance was one of the areas to be reformed and expanded.

Möller's model of social insurance, which was not altogether explicitly formulated, was founded on basic security for the whole population. Payments were to be made as standard benefits, and they were to be largely financed by taxes. Over and above this, individuals were to be responsible for guaranteeing their own income. Insurance against industrial injury, which was to be financed by the employers and to provide compensation for loss of income, was separate from other forms of social insurance. Möller's model shows great similarites to, and was inspired by, 
the Beveridge Plan. The greatest difference of principle was that Beveridge to a large extent used contributions as the source of finance. Möller also had the ambition of redistributing incomes for the benefit of low earners. Another source of inspiration for Möller was the Dane K. K. Steincke, who had developed an idea back in the 1910s that social insurance should be tax-financed and be a civil right.

In 1946 the Swedish parliament decided, following proposals by Möller, to introduce a general old-age pension and general sickness insurance. In 1948 the parliament enacted a distinct improvement in insurance against industrial injuries. These decisions corresponded to the intentions of the Möller model. However, the sickness insurance, which was not to come into force until 1950, was later postponed. From the end of the 1940s, voices began to question the decision about sickness insurance from 1946. The favourable economic development after the war, with rising wages, led to growing demands for compensation for lost income. Increased interest in work-environment issues and the coordination of sickness insurance and industrial injury insurance also contributed to this. Finally, it became clear that tax financing would be far too expensive for the state; more financing through contributions was thus advocated. In 1953 the decision of 1946 was reconsidered, and a completely new sickness insurance was introduced, coordinated with industrial injury insurance and based on the principle of lost income.

No general unemployment insurance was introduced. The proposal of a committee of inquiry was presented in 1948, but the union organizations, which had their own unemployment insurance funds, were opposed to it. In addition, there was full employment at the time, so general unemployment insurance was not viewed as an important political issue.

Möller's model of social insurance did not suit the Swedish post-war environment. Only the old-age pension was to survive. It is an irony of history, however, that the Conservative Party and the Agrarian Party were the first Swedish parties to advocate a tax-financed old-age pension. 